\section{TexFirst, an Early-ripening, Low-chill Peach for the Subtropics}

\author{
David H. Byrne ${ }^{1}$ and Natalie Anderson \\ Department of Horticultural Sciences, Texas A\&M University, Horticulture- \\ Forestry Science Building, College Station, TX 77843-2133
}

Additional index words. fruit breeding, low chilling, Prunus persica

'TexFirst' is being released by Texas A\&M University to provide a low-chilling commercially acceptable peach that ripens $\approx 1$ week before 'Flordaking'. This attractive, yellow-flesh peach ripens in late April to mid-May in the low and medium chill zones of the United States.

\section{Origin}

This peach tree [Prunus persica (L.) Batsch] originated in the Stone Fruit Breeding Program at Department of Horticultural Sciences at Texas A\&M University, located in College Station, TX. The seed parent was the Thai Tiger peach TXW1193-1 (Byrne and Boonprakob, 2008), a cultivar jointly released by Texas A\&M University and Kasetsart University (Kampangsaen, Nakhonpathom, Thailand). Open-pollinated seed from Thai Tiger TXW1193-1 was planted in a highdensity fruiting nursery at College Station in 1996. From this progeny, the seedling denominated as TX1A95 was selected for its early maturity, good productivity, yellow ground color, round shape, high red overcolor, and excellent firmness. It was propagated asexually by budding and has been evaluated in Texas and California.

\section{Description}

'TexFirst' has been fruited in two locations: a medium chill site (Floresville, TX) and a high chill location (Fowler, CA). Floresville, TX (lat. $29^{\circ} 11^{\prime} \mathrm{N}$, long. $98^{\circ} 5^{\prime} \mathrm{W}$, $155 \mathrm{~m}$ elevation) is southeast of San Antonio, TX. The mean monthly temperature of its coldest month averages $\approx 11.6{ }^{\circ} \mathrm{C}$, which corresponds to a chilling accumulation generally above 450 chill units (Byrne and Bacon, 1992; Sharpe, 1970; Weinberger, 1956). The Fowler, CA, site (lat. $36^{\circ} 38^{\prime} \mathrm{N}$, long. $119^{\circ} 42^{\prime} \mathrm{W}$, $92 \mathrm{~m}$ elevation) has a mean monthly temperature of its coldest month of $7.8^{\circ} \mathrm{C}$ and has a chilling accumulation that is generally above 800 chilling units (Table 1 ).

'TexFirst' trees flower and leaf with 'TropicPrince' (Byrne, 2002) and 'TropicBeauty'

Received for publication 16 July 2012. Accepted for publication 12 Sept. 2012.

Research conducted at the Department of Horticultural Sciences, College Station, TX.

${ }^{1}$ To whom reprint requests should be addressed; e-mail dbyrne@tamu.edu.
(Rouse and Sherman, 1989) and 15 to $21 \mathrm{~d}$ before 'Flordaking' (Andrews et al., 1979) and 'TexKing' (Byrne and Bacon, 2004) (Table 2). Thus, its chilling requirement is rated at $\approx 150$ to 200 chilling units (hours below $7{ }^{\circ} \mathrm{C}$ ).

'TexFirst' is being released for use in the medium chill zones where 'Flordaking' and 'TexKing' are adapted. This new peach can be used with frost protection to consistently yield a high-quality peach that ripens 1 week before 'Flordaking' (Table 2). 'TexFirst' can also be grown in areas where the trees of 'TropicPrince' and 'TropicBeauty' are produced commercially but has not been extensively tested in this zone. Sharpe, 1970; Weinberger, 1956)

Fig. 1. 'TexFirst' peach harvested 22 Apr. in Floresville, TX.
'TexFirst' bears crops of early-ripening peaches that are firm and a good size for the season. The fruit is round with a flattened tip, has a yellow ground color, $40 \%$ to $80 \%$ striped orange red [Royal Horticultural Society (RHS) orange-red 34A to N34A; Anon., 1995)] to red (RHS red 42A) overcolor, yellow to orange (RHS yellow group 4A-C and $9 \mathrm{D}$ and orange group 24B-C) flesh color, and is a melting-flesh clingstone (Fig. 1). The fruit flesh does not brown readily nor has it shown a tendency to develop split or shattered pits during the final stage of fruit swelling. In the Floresville site, the fruit, although smaller, ripen earlier and have better firmness, percent red overblush, shape, and overall appearance than either 'Flordaking' or 'TexKing' (Table 2). At the higher chill site, in California, the fruit was rounder than either cultivar but was only superior to 'Flordaking' with respect to firmness, percent red over blush, ground color, and overall appearance (Table 2). Its quality as measured by total soluble solids and a rating of flavor is equal to that of the other major cultivars (Table 2).

The tree is vigorous with a semispreading growth habit as are trees of 'TropicPrince' 'TropicBeauty', and 'TexKing'. No observations have been made on resistance for either

Table 1. Chilling conditions at Floresville, TX, and Fowler, CA, evaluation sites.

\begin{tabular}{|c|c|c|c|c|c|c|c|}
\hline \multirow[b]{2}{*}{ Location } & \multicolumn{2}{|c|}{$\begin{array}{l}\text { December } \\
\text { temp }\left({ }^{\circ} \mathrm{C}\right)\end{array}$} & \multicolumn{2}{|c|}{$\begin{array}{c}\text { January } \\
\text { temp }\left({ }^{\circ} \mathrm{C}\right)\end{array}$} & \multicolumn{2}{|c|}{$\begin{array}{c}\text { Chilling } \\
\text { accumulation }^{z}\end{array}$} & \multirow[b]{2}{*}{ Common cultivars } \\
\hline & Mean & Range & Mean & Range & Mean & Range & \\
\hline Floresville $^{y}$ & 11.7 & $8.2-13.4$ & 11.5 & $9.1-14.6$ & 657 & $404-939$ & $\begin{array}{l}\text { TexKing, Flordaking, } \\
\text { TexPrince }\end{array}$ \\
\hline Fowler & 7.6 & $5.3-10.3$ & 7.9 & $5.1-12.0$ & 1121 & $788-1301$ & O'Henry, Elegant Lady \\
\hline
\end{tabular}

${ }^{\mathrm{z}}$ Chilling estimated with the mean monthly temperatures of the two coldest months using the equation chilling $=4280-\left(68.8 *\right.$ December/January mean monthly temperature in $\left.{ }^{\circ} \mathrm{F}\right)$ (Byrne and Bacon, 1992;

${ }^{y}$ Floresville used data from San Antonio and the Fowler used data from the Fresno weather station.

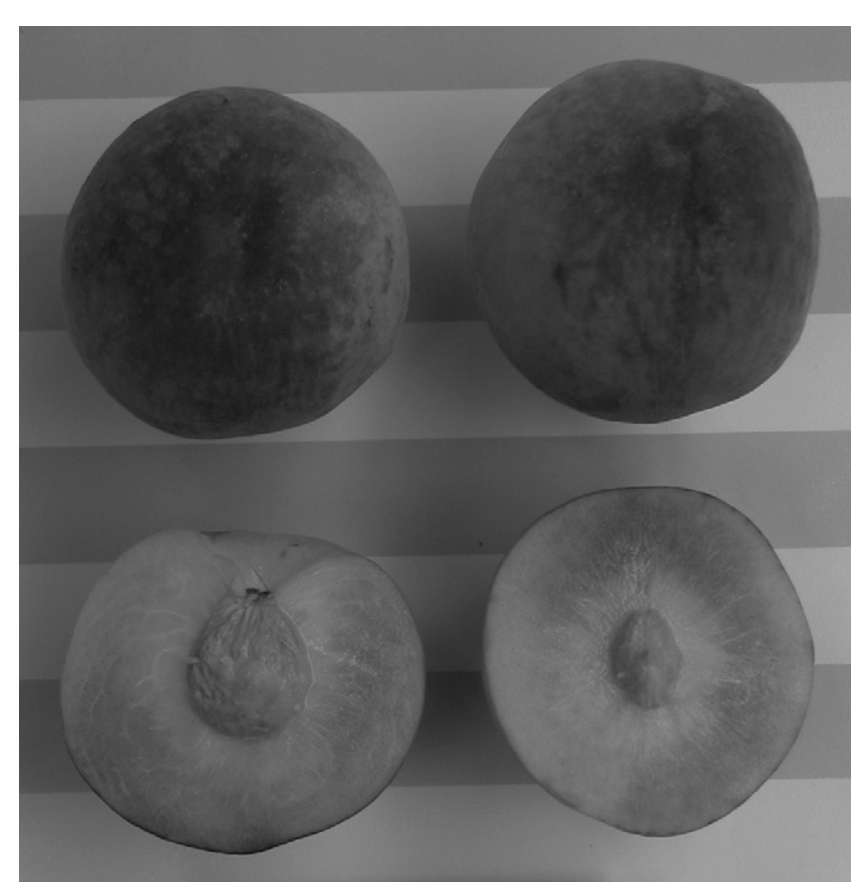


Table 2. Fruiting characteristics of 'TexFirst' compared with 'Fordaking' and 'TexKing' at Floresville, TX (2003-10) and Fowler, CA (2000-10).

\begin{tabular}{|c|c|c|c|c|c|c|c|c|c|c|c|c|c|}
\hline Name & $\begin{array}{c}\text { Full } \\
\text { bloom }\end{array}$ & $\begin{array}{c}\text { FDP } \\
(\text { days })^{z}\end{array}$ & $\begin{array}{l}\text { Ripe } \\
\text { date }^{z}\end{array}$ & $\operatorname{Size}^{\mathrm{y}}$ & Wt (g) & Firmness $^{x}$ & Blush $^{x}$ & Shape ${ }^{x}$ & $\operatorname{Tip}^{x}$ & $\begin{array}{l}\text { Ground } \\
\text { color }^{x}\end{array}$ & Appearance $^{\mathrm{x}}$ & $\begin{array}{c}\text { Soluble } \\
\text { solids (\%) }\end{array}$ & Taste $^{x}$ \\
\hline TexFirst & 29 Jan. & 87 & 26 Apr. & 4.9 & 109 & 7.3 & 7.2 & 7.9 & 7.9 & 7.0 & 7.8 & 10.0 & 6.2 \\
\hline Flordaking & 18 Feb. & 78 & 3 May & 6.2 & 137 & 6.2 & 3.4 & 5.7 & 5.9 & 6.1 & 5.5 & 9.3 & 5.7 \\
\hline Significance $^{\mathrm{w}}$ & $* * *$ & $* * *$ & $* * *$ & $* * *$ & $* * *$ & $* * *$ & $* * *$ & $* * *$ & $* * *$ & $* *$ & $* * *$ & NS & NS \\
\hline \multicolumn{14}{|c|}{ Fowler, CA (2000-10) } \\
\hline TexFirst & $10 \mathrm{Feb}$. & 96 & 17 May & 5.8 & 134 & 7.5 & 6.0 & 8.1 & 8.6 & 6.9 & 7.0 & 10.0 & 6.4 \\
\hline Significance $^{\mathrm{w}}$ & $* * *$ & NS & $* * *$ & * & NS & * & $* * *$ & $* * *$ & $* * *$ & NS & $*$ & NS & NS \\
\hline
\end{tabular}

${ }^{\mathrm{z}}$ Full bloom $=60 \%$ to $80 \%$ flowers open; FDP $=$ fruit development period, number of days from full bloom to ripe; Ripe date $=$ date when $20 \%$ fruit is at the firm ripe stage.

${ }^{y}$ Size ratings of diameter $(\mathrm{mm}) 0-9,4=51-57,5=58-64,6=65-70,7=71-76$.

${ }^{x}$ Rating scale $0-9 ; 0-4=$ unacceptable, $5=$ marginal, $6=$ good, $7=$ very good, $8-9=$ excellent for commercial use.

wDifferences among the mean values of full bloom, ripe date, FDP, weight, and soluble solids were evaluated with an analysis of variance, whereas the mean values of the rating data (size, firmness, blush, shape, tip, appearance, ground color, and taste) were evaluated by the non-parametric Kruskal-Wallis test.

NS $=$ nonsignificant, $* 0.05, * * 0.01$, and $* * * 0.001$ significance probability

peach rust (Tranzschelia discolor) or bacterial leaf spot (Xanthomonas campestris pv. pruni). The moderately large leaves are lanceolate with acute bases, sharply acute apices, crenulate margins, and reniform petiolar glands.

Flowers are showy with a diameter between 28 and $32 \mathrm{~mm}$ and petal length of $15 \mathrm{~mm}$. The five petals are light pink (RHS white group N155B-C) becoming darker near the petal claw. The sepals are dull red (RHS greyed orange group 176A-B). The golden yellow (RHS yellow-orange 17A-B) anthers are on filaments (15 mm length) and are slightly shorter than the pistil (15 to $17 \mathrm{~mm}$ including ovary). The filaments are white tinged with pink (RHS white group 155A-D) and darken with age. Pollen is yellow and abundant. The tree is self-fertile.

The stones are of medium size with the dimensions of 27 to $30 \mathrm{~mm}$ in length, 23 to
$25 \mathrm{~mm}$ in width, and $\approx 17 \mathrm{~mm}$ in thickness. The dry stone surface is a light brown color (RHS greyed orange group 164B-C) and is considered medium to medium smooth in roughness with substantial pitting laterally.

\section{Availability}

Burchell Nursery, Inc. has a license to propagate this variety for California, Arizona, and Mexico. For interests in other areas, requests for budwood should be directed to the Texas A\&M University System's Office of Technology Commercialization. This variety is the subject of a plant patent application.

\section{Literature Cited}

Andrews, C.P., W.B. Sherman, and P.M. Lyrene. 1979. 'Flordaking' peach. HortScience 14:81-82.
Anon, 1995. RHS colour chart. The Royal Hort. Soc., London, UK.

Byrne, D.H. 2002. Peach tree named 'Tropicpeachone'. U.S. plant patent 12,965. 17 Sept. 2002.

Byrne, D.H. and T.A. Bacon. 1992. Chilling estimation: Its importance and estimation. The Texas Horticulturist 18:5, 8-9.

Byrne, D.H. and T.A. Bacon. 2004. 'TexKing', an early ripening medium chill peach. HortScience 39:442-443.

Byrne, D.H. and U. Boonprakob. 2008. Thai Tiger $^{\mathrm{TM}}$ series of low-chill peaches for the subtropics. HortScience 43:2226-2227.

Rouse, R.E. and W.B. Sherman. 1989. 'TropicBeauty': A low-chilling peach for subtropical climates. HortScience 24:165-166.

Sharpe, R.H. 1970. Sub-tropical peaches and nectarines. Fla. State Hort. Soc. 82:302-306.

Weinberger, J.H. 1956. Prolonged dormancy trouble in peaches in the southeast in relation to winter temperatures. Proc. Amer. Soc. Hort. Sci. 67:107-112. 